\title{
Bisfenol A ve erkek üreme sağlığı
} Bisphenol A and male reproductive health

\author{
Tuğba Gündoğdu®, Yasemin Akdevelioğlu²®
}

\section{öz}

Bisfenol A (BPA) epoksi reçine yapımında ve polimer olmayan plastiklerde katkı maddesi olarak kullanılan endokrin sistem üzerine olumsuz etkileri olan bir kimyasaldır. BPA'nın dünya genelinde üretimi zaman içinde artış göstermiştir. İnsanlar genelde yiyecek ve içeceklerin kontaminasyonu ile BPA'ya maruz kalmaktadır. Östrojen ve androjen reseptörlerin işlevini ve ekspresyonunu modüle edebilen BPA hem östrojenik hem de anti-androjenik etkilere sahiptir. Bu etkilerinden dolayı erkek üreme sağlığını olumsuz etkileyebilmektedir. Farelerin gestasyon veya yetişkinlik dönemlerinde yapılan çalışmalarda önerilen günlük alım düzeyindeki BPA miktarı ya da çevresel BPA maruziyetine eş değer verilen BPA dozları farelerde erkek üreme sağlığını olumsuz etkilemiştir. Mevcut çalışmalarda, farelerde sperm sayısında ve rezervinde, spermin epididimden geçiş süresinde ve testesteron hormon seviyesinde azalmalar gözlenmiştir. Fare çalışmaları BPA'ya özellikle utero dönemindeki maruziyetin daha büyük ve kalıcı etkilere neden olabileceğini rapor etmiştir. Nükleer morfolojideki değişikliklerin ve DNA metilasyonu gibi epigenetik mekanizmaların BPA gibi çevresel kontaminantlara yanıt olarak üreme sağlığı üzerinde olumsuz etkilere neden olabilecek potansiyel mekanizmalar olabileceği düşünülmektedir. BPA ve erkek üreme sağlığı ilişkisini inceleyen insan çalışmaları ise genelde epidemiyolojik çalışmalardır ve bazı çalışmalarda idrar BPA düzeyleri anormal semen parametreleri ile ilișkilendirilmiștir. Calıșmalarda BPA'nın steroid hormonlar üzerine etki gösterdiği de bulunmuştur. Ancak, çalışmalar bu konuda tutarsız sonuçlar vermektedir. Sonuç olarak, endokrin sistem üzerine olumsuz etkileri ile BPA çok düşük dozlarda bile erkek üreme sağlığı üzerinde ciddi düzeyde olumsuz etkilere neden olabilmektedir. İnsan çalışmaları genellikle BPA’nın yetişkin dönemindeki erkek maruziyetini ölçmüştür ve BPA'nın etkilerine daha duyarlı olabilecek erken yaşam dönemlerini kapsayan (örn., prenatal veya peripubertal dönemler gibi) çalışmalar yetersiz sayıdadır.

Anahtar Kelimeler: Erkek üreme sağlığı, bisfenol A, fertilite, seks hormonları

'Sağlık Bilimleri Üniversitesi Antalya Eğitim ve Araştırma Hastanesi, Beslenme ve Diyet Bölümü, Antalya, Türkiye

${ }^{2}$ Gazi Üniversitesi Sağık Bilimleri Fakültesi, Beslenme ve Diyetetik Bölümü, Ankara, Türkiye

\section{Yazışma Adresi / Correspondence:}

Tuğba Gündoğdu

Antalya Eğitim ve Araştırma Hastanesi, D Blok, 2. Kat, Diyetisyen Odası, Muratpaşa/

Antalya 07000 Antalya, Türkiye

Tel. $\quad+905539078238$

E-mail: tugbaerolll@hotmail.com

Gelis / Received: $\quad 24.07 .2018$

Kabul / Accepted: 06.09.2018

\section{ABSTRACT}

Bisphenol A (BPA) is an endocrine disrupting chemical used as an additive in epoxy resin making and non-polymer plastics. BPA's worldwide production has increased over time. People are generally exposed to BPA through the contamination of food and beverages. BPA, which modulates the function and expression of estrogen and androgen receptors, has both estrogenic and anti-androgenic effects. Because of these effects, male reproductive health can be adversely affected. BPA levels given at doses equivalent to recommended daily intake or environmental exposure in gestation or adulthood studies of rats negatively affected male reproductive health in mice. In current studies, sperm count and reserve in rats, sperm epididymal transition and testosterone hormone levels decreased. Rat studies have reported that exposure to BPA, especially during the in utero period, may cause greater and more permanent effects. Changes in nuclear morphology and epigenetic mechanisms such as DNA methylation are thought to be potential mechanisms that may cause adverse effects on reproductive health in response to environmental contaminants such as BPA. Human studies examining the relationship between BPA and male reproductive health are generally epidemiological studies and in some studies urinary BPA levels have been associated with abnormal sperm parameters. Studies have also shown that BPA also affects steroid hormones. However, the studies give inconsistent results in this regard. As a result, endocrine disrupting effect can cause serious adverse effects on male reproductive health even at very low doses of BPA. Human studies often measure BPA's adult male exposure and are inadequate in studies involving early life periods (eg, prenatal or peripubertal periods), which may be more sensitive to the effects of BPA.

Keywords: Male reproductive health, bisphenol A, fertility, sex hormones

\section{Gíriș}

Bisfenol A, (BPA, 2,2-bis (4-hidroksifenil) propan) polikarbonat plastik yapısındaki epoksi reçine yapımında ve polimer olmayan diğer plastiklerde katkı maddesi olarak endüstride sıklıkla kullanılan endokrin sistem üzerine olumsuz etkileri olan bir kimyasaldır. Endokrin sistemi olumsuz etkileyen kimyasallar, endokrin sistemin gelişimi ve fonksiyonunda farklı düzeylerde değişime yol açan ekzojen madde veya madde karışımlarıdır. ${ }^{[1]}$ Amerika Birleşik 
Devletleri (ABD) Çevre Koruma Ajansı (U. S. EPA) endokrin sistemin işlevini olumsuz etkileyen maddeleri hedef reseptör veya dokudaki hormonların etkisini durduran veya taklit eden ya da direkt olarak endokrin sistem hormonlarının üretimini stimüle veya inhibe eden kimyasallar olarak tanımlamıştır. ${ }^{[2]}$ BPA yapılan çoğu çalışmada östrojenik özellik göstermesinden dolayı endokrin sistemi olumsuz etkileyen bir kimyasal olarak nitelendirilmiştir. ${ }^{[1]} \mathrm{BPA}$ ilk olarak 1891'de Dianin tarafından bildirilmiştir. Daha sonra $1905^{\prime}$ te Zincke tarafindan fenol ve asetondan sentezlenmiştir. ${ }^{[3]} 1930$ 'lardan beri ise sentetik estradiol olarak ticari kullanımda yer almaktadır. ${ }^{[4]}$ Dünyada en yaygın olarak üretilen ve kullanılan kimyasallardan biri olan BPA, [5] 2002 yilında dünyada toplam 2,8 milyon ton ve 2011 yılında ise tahmini 5,5 milyon ton üretilmiştir. ${ }^{[6]} \mathrm{BPA}$ üretiminde en fazla büyüme Asya'da ortalama yıllık \%13 ve Hindistan'da polikarbonatların talebinde $\% 19$ büyüme ile gözlemlenmektedir. ${ }^{[4]} \mathrm{BPA}$ insan vücuduna esas olarak kontamine yiyecek ve içme suyunun tüketilmesi ile girmektedir. Ayrıca, çevreden (kirli hava ve sudan), ev ürünlerinden, kozmetik ürünlerden, medikal ürünlerden (kontamine ekipman ve cihazlar) ve üretim süreçlerinde veya endüstriyel kullanım sırasında inhalasyon ve dermal temas ile vücuda alınabilmektedir. Oral alım, besinlerin plastik torbalarda 1 sıl işlem görmesi ile veya pişirme işleminden önce ambalajlanması gibi BPA'nın torbadan besine sızmasını artıran besin hazırlama uygulamaları ile olabilmektedir. Mikrodalga fırınların üretiminde kullanılmaya başlandı ̆̆ı bilinen BPA’ya oral maruziyet epoksi reçine bazlı gıda kutularının, su şişelerinin veya plastik biberonların kullanımı ile de olabilmektedir. ${ }^{[7]}$ Ayrıca, dental ürünlerin (diş macunları ve kompozit dolgular) kullanımı ile de BPA'ya maruz kalınabilmektedir. ${ }^{[6]}$ Konserve gıda tüketimi yoluyla insandaki BPA maruziyetinin $6,6 \mu \mathrm{g} / \mathrm{kişi} / \mathrm{gün}$ olduğu tahmin edilmektedir. ${ }^{[4]}$ U. S. EPA tarafından BPA için gözlenebilen hiçbir yan etki göstermeyen doz (NOAEL) ve en düşük gözlenen etki seviyesi (LOAEL) değerleri sırası ile 5 ve $50 \mathrm{mg} / \mathrm{kg} /$ vücut ağırlığı olarak tanımlanmıştır. ${ }^{\left[{ }^{[]}\right.}$Avrupa Gıda Güvenliği Kurumu (EFSA) tarafından ise $50 \mu \mathrm{g} / \mathrm{kg}$ vücut ağırlığı/gün tolere edilebilir bir günlük alım değeri (TDI) belirlenmiştir. ${ }^{[9]}$ Ancak, yetişkin kemirgenlerde yapılan çalışmalarla insanlar için kabul edilebilir günlük alım dozu belirlenirken, gelişme döneminde BPA maruziyetine karşı hassasiyetin önemli ölçüde arttığı bilgisinin göz ardı edilmesi güvenli doz ile ilgili endişeler duyulmasına neden olmuştur. ${ }^{[10]}$ Bu nedenle, EFSA 2015 Ocak ayında BPA'nın TDI değerini $4 \mu \mathrm{g} / \mathrm{kg} / \mathrm{gün}$ seviyesine düşürdüğünü bildirmiştir. ${ }^{[11]}$ Çeşitli yollar ile insanlara bulaşan BPA temelde karaciğer glukuronidasyon yolunda metabolize edilmektedir. BPA’nın biyolojik yarı ömrü yaklaşık 6 saattir ve 24 saatte idrarla neredeyse tamamı atılmaktadır.
Hızlı metabolize olmasına rağmen, BPA oldukça uzun bir süre dokularda birikebilir ve konjugasyon-dekonjugasyon döngüsüne dahil olabilir. ${ }^{[12]} \mathrm{BPA}$; serum, kan ve plazma, gebelikle ilişkili sıvılarda (amniyon sıvısı, plasenta dokusu ve göbek kordon kanı), anne sütünde, üre, semen ve foliküler sıvıda olmak üzere vücudun çeşitli doku ve sıvılarında bulunmaktadır. ${ }^{[13]}$ ABD nüfusunun \%90'ının idrar örneklerinde BPA'ya rastlanmıştır ve yetişkinlerde ortalama idrar BPA seviyesinin yaklaşık $2,5 \mathrm{ng} / \mathrm{ml}$ olduğu ve kanda konjuge edilmemiş veya serbest BPA konsantrasyonunun yaklaşık $1 \mathrm{ng} / \mathrm{ml}$ olduğu belirlenmiştir. Ayrıca, maternal plazmada $0,3-18,9$, fetal plazmada $0,2-9,2$ ve anne sütünde $0,28-0,97 \mathrm{ng} / \mathrm{ml}$ düzeylerinde BPA saptanmıştır. ${ }^{[14]}$ BPA'ya LOAEL veya insanlar için güvenli dozun altındaki düzeylerde gelişimsel maruziyetin sayısız olumsuz etkileri olduğu bilinmektedir. Bu etkiler arasında şunlar vardır: Puberte zamanının değişmesi; değişmiş östrus siklusu, prostat değişiklikleri, neoplazilerin gelişimi de dahil olmak üzere yetişkinlikte değişmiş meme bezi gelişimi, rahim ve yumurtalıktaki değişiklikler, beyin cinsel dimorfizmlerinde değişiklikler, beyinde ve beyin steroid reseptör seviyelerinde ve reseptör transkriptlerinde ek değişiklikler, hiperaktivite raporlarını içeren davranış değişiklikleri, artan saldırganlık, değişmiş sosyoseksüel davranışlar, değişmiş bilişsel ve anksiyolitik davranışlar, bağımlılık ilaçlarına artan duyarlılık, değişmiş vücut ağırllğı ve vücut kompozisyonu ve değişmiş glukoz homeostazı. ${ }^{[10]} \mathrm{Bu}$ derlemede ise güncel literatür bilgileri ışığında BPA'nın erkek üreme sağlığı üzerine etkileri irdelenmektedir.

\section{ERKEK ÜREME SAĞLIĞI}

Erkek fertilitesi, testislerin seminifer tübülleri içinde meydana gelen, erkek germ hücre gelişiminin çok aşamalı prosesi olan spermatogenezin başarılı şekilde sürdürülmesine bağlıdır. Seminifer tübüllerdeki üç ana hücre tipinden biri olan sertoli hücreleri germ hücrelerinin çoğalması ve farklılaşması için gerekli faktörleri sağlar. Leydig hücreleri tübüller arasındaki interstisyel boşlukta bulunur ve seminifer tübüllerin yanı sıra interstisyel alanda kan damarlarına yayılan testosteronu üretir. ${ }^{[15]}$ Fetal yaşam sırasında spermatogenez, germ hücrelerinin mevcut ön-madde havuzunu arttırmak için birkaç mitotik bölünmeye maruz kalan spermatogonia olarak bilinen farklılaşmamış diploit hücrelerden seminifer tübüllerin duvarında başlar. Puberte döneminde, bazı spermatogonialar, ilk mayoz bölünme sürecine girerek haploid tip II spermatositleri üretecek olan tip I spermatositlere dönüşür. Bu hücrelerde, haploit spermatidleri açığa çıkaran ikinci bir mayoz bölünme meydana gelir. Spermatogenezin son aşaması, yuvarlak spermatidin morfolojik ve yapısal transformasyon kompleksi ile 
karakterize edilen spermiyogenez ile temsil edilir. Hücre bölünmesi olmaksızın ortaya çıkan bu adım, sperm motilitesi ve dölleme kapasitesi için gerekli olan temel unsur olan flagellum ve akrozomun ayırt edilmesiyle karakterize olgun sperm üretimine yol açmaktadır. ${ }^{[16]}$

Testislerin genel hormonal kontrolü ise, hipotalamik-hipofizer aks tarafindan korunur ve gonadotropinlerin salgılanmasını düzenleyen hipotalamus tarafindan salgılanan gonadotropin salgılatıcı hormon $(\mathrm{GnRH})$ ve hipofizden salgılanan luteinize edici hormon (LH) ile folikül uyarıcı hormon (FSH) tarafindan sağlanır. GnRH leydig hücrelerden testesteron salgısını düzenleyen hipofiz bezinden gonadotropin (FSH ve LH) sekresyonunu kontrol ederek üreme fonksiyonunun tüm endokrin regülasyonunu düzenler. FSH esas olarak sertoli hücrelerine etki etmek amaciyla hipofizden üretilir ve gönderilir. Sertoli hücresi tarafından salgılanan inhibinin ise FSH üretimini inhibe etmek için testisten hipofize bir geri besleme döngüsüne dahil olduğuna inanılmaktadır ${ }^{[17]}$ Yukarıda belirtilen mekanizmayı bozarak erkek infertilitesine neden olan genetik, kimyasal ve çevresel etkenlerin potansiyel riskinin farkındalığı artmaktadır. ${ }^{[18]}$ Özellikle kimyasal faktörler arasından insan sağlığını ciddi düzeyde tehdit eden BPA dikkat çekmektedir.

BPA'nın erkek üreme sağlığı üzerindeki zararlı etkisi, embriyonik, pubertal ve/veya yetişkinlik döneminde ortaya çıkabilir. Hormon sentezini, ilgili reseptörlerin ekspresyonunu ve fonksiyonunu modüle ederek hipotalamik-hipofiz-testiküler aksı etkileyen BPA sperm parametrelerini değiştirmekte, üreme bozuklukları ve infertilite ile ilişkilendirilmektedir. Ayrıca, BPA antioksidan enzimleri inhibe ederek ve lipid peroksidasyonunu uyararak testis ve epididimde oksidatif strese neden olmaktadır. ${ }^{[7]}$ BPA'nın östrojen (ER) ve androjen reseptörleri (AR) ile etkileşim yoluyla hem östrojenik hem de anti-androjenik etkilere sahip olduğu bildirilmiştir.
[19] BPA'nın 17-beta estradiol (E2)'e göre nükleer estrojen reseptörleri için daha düşük bir afiniteye sahip olduğu bilinmesine rağmen, östrojenik potansiyeli nükleer olmayan östrojen reseptörlerinin aracılık ettiği yanıtlar için E2'ye eşittir. Ayrıca, BPA bir anti-östrojen olarak etki göstererek, endojen E2 ile rekabet ederek östrojenik yanıtı bloke edebilmektedir. ${ }^{[6]}$ E2'nin hipotalamus/hipofizde ER'lere bağlanmasının rekabetçi bir inhibisyonu, dolaşımdaki E2'nin LH üzerindeki negatif geri beslemesinin zayıflamasına yol açarak, dolaşımda artmış düzeyde LH konsantrasyonları ile sonuçlanabilecek ve bu da testisin E2 üretiminin artmasina neden olabilecektir. Aynı zamanda BPA, AR antagonisti olarak normal AR bağlanma aktivitesini kesintiye uğratabilir ve reprodüktif fonksiyonla bildirilen ilişkileri ve potansiyel olarak endokrin fonksiyonları değiştirebilir. Örneğin, hipotalamus/hipofiz üzerinde bir etkiye neden olarak E2 üretimini arttırabilir. ${ }^{[20]}$ Son olarak, BPA tiroid reseptörlerine bağlanarak tiroid fonksiyonu üzerinde hem agonistik hem de antagonistik etkilere sahiptir. $^{[6]}$

\section{HAYVAN ÇALIȘMALARI}

BPA ve erkek üreme sağlığı ilişkisini inceleyen çalışmalar birçok araştırmacı tarafından deney hayvanlarında yürütülmüştür (Tablo 1). Öncelikle 1998 yılında vom Saal ve arkadaşları, erkek fareler üzerinde prenatal BPA maruziyeti üzerinde çalışmışlar ve preputial bezler için artan boyut ve düşük epididimis boyutu ve ayrıca günlük sperm üretiminin azaltılmış etkinliğini araştırmışlardır. ${ }^{[21]}$ Gestasyonel dönemde yapılan diğer hayvan çalışmaları incelendiğinde; gestasyonun 11 ile 17. gün aralığında dişi farelere günde 2-20 ng/g vücut ağırlığı/gün oral yoldan BPA verilmesi, 8 ve 12 haftalık erkek yavruların nispi testis ağırlığında belirgin bir azalma ile sonuçlanmıştır. ${ }^{[22]} \mathrm{Xi}$ ve arkadaşları tarafından yapılan başka bir çalışmada ise dişi farelere eş

Tablo 1. Deney hayvanlarında yapılan çeşitli çalışmalar

\begin{tabular}{|c|c|c|c|c|}
\hline Referans & Denekler & BPA dozu & süre & Sonuç \\
\hline $\begin{array}{l}\text { Liu ve ark. } \\
\text { 2013. }\end{array}$ & Fareler & $\begin{array}{l}0,2,20 \text { veya } \\
200 \mu \mathrm{g} / \mathrm{kg} / \mathrm{gün}\end{array}$ & 60 gün & $\begin{array}{l}200 \mu \mathrm{gg} / \mathrm{kg} \text { / gün BPA ile sperm sayısında } \\
\text { önemli ölçüde azalma }\end{array}$ \\
\hline $\begin{array}{l}\text { Karnam ve } \\
\text { ark. 2015. }{ }^{[49]}\end{array}$ & 24 fare & $\begin{array}{l}50 \mathrm{mg} / \mathrm{kg} \\
200 \mathrm{mg} / \mathrm{kg} \\
600 \mathrm{mg} / \mathrm{kg}\end{array}$ & 28 gün & $\begin{array}{l}200 \text { ve } 600 \text { mg/kg BPA farelerde epididimal sperm } \\
\text { sayısında azalma, sperm ölü sayısı ve baş ve kuyruk } \\
\text { anormalliği yüzdesinde artş }\end{array}$ \\
\hline $\begin{array}{l}\text { Nanjappa ve } \\
\text { ark. 2012. }{ }^{[14]}\end{array}$ & 14 fare & 2,5 ve $25 \mu / \mathrm{kg} /$ gün & $\begin{array}{l}\text { Gestasyonun } \\
\text { 12. gününden } \\
\text { pospartum 21.güne } \\
\text { kadar }\end{array}$ & $\begin{array}{l}\text { Leydig hücre farklılaşmasında bozulma } \\
\text { Testesteron üretiminde baskılanma }\end{array}$ \\
\hline $\begin{array}{l}\text { Salian ve } \\
\text { ark. 2009. }{ }^{[50]}\end{array}$ & 32 fare & 1.2 and $2.4 \mu \mathrm{g} / \mathrm{kg}$ & $\begin{array}{l}\text { Gestasyonun } \\
\text { 12. gününden } \\
\text { pospartum 21.güne } \\
\text { kadar }\end{array}$ & $\begin{array}{l}\text { F1 erkek yavrularında sperm sayısı ve motilitesinde } \\
\text { azalma (Bu etkiler F2 ve F3 farelerinde daha belirgin) } \\
\text { LH, FSH, E ve Testesteron seviyelerinde anlamlı azalmalar } \\
\text { Testis dokusunda androjen reseptörü ve Er } \beta \\
\text { ekspresyonunda anlamlı düşüşler }\end{array}$ \\
\hline
\end{tabular}


zamanlı olarak BPA ve di (2-etilheksil) fitalat (başka bir plastik bileşen) uygulandığında, maruz kalan erkek yavruların testislerinde Anti-Müllerian Hormonunun (AMH) ve Steroidojenik Akut Düzenleyici Proteinin (StAR) ekspresyon seviyelerinde ve yavruların testis büyüklüklerinde azalma olduğu bildirilmiştir. Olumsuz etkilerin yavrularda doğum sonrası 42. günde kalıcı olarak gözlendiği ve yavruların epididimal sperm sayılarının önemli ölçüde azaldığı rapor edilmiştir. ${ }^{[23]}$ Ancak, gebe sıçanlarda yapılan bir başka çalışmada ise gestasyonun 7 . gününden postnatal 18. güne kadar 2-200 $\mu \mathrm{g} / \mathrm{kg} /$ gün BPA ile beslenen farelerin erkek yavrularında olumsuz bir üreme etkisinin gözlenmediği bildirilmiştir. ${ }^{[24]}$ Pubertal dönemdeki sıçanlar ve fareler üzerinde yapılan bir çalışma incelendiğinde ise hayvanların deri altı enjeksiyonlar ile 5 hafta boyunca 3 $\mathrm{mg} / \mathrm{kg} /$ gün BPA'ya maruz kalması, daha düşük epididimal spermatozoa ve testosteron konsantrasyonları ile sonuçlanmıştır. ${ }^{[25]}$ Yetişkin fareler üzerinde yapılan çalışmalar incelendiğinde; Wisniewski ve ark., yürüttükleri bir çalışmada 30 erkek yetişkin farede (3 grup, 10 fare/grup), BPA'nın üreme sistemi üzerindeki toksik etkilerini güvenli olduğu düşünülen dozajlarda araştırmışlardır. Hayvanlar doğum sonrası 50. günden 90. güne kadar 0, 5 veya $25 \mathrm{mg} / \mathrm{kg} /$ gün BPA almışlardır. Yetişkin farelerde BPA'ya maruz kalmanın; toplam ve günlük sperm üretimini $5 \mathrm{mg} / \mathrm{kg}$ ve 25 mg/kg'lık dozajlarda \%50 azalttığı, tüm BPA ile tedavi edilen gruplar için epididimin tüm bölümlerinde sperm rezervinin en az \%70 azaldığ , sperm geçiş süresinin kaput, korpus ve kauda epididimde \%50 oranında azaldığı bulunmuştur. Ayrıca mevcut çalışmada, BPA ile tedavi edilen hayvanların akrozomlarında ve plazma membranında daha yüksek seviyede hasar, mitokondriyal aktivitelerinde azalma ve hasarlı spermatozoa düzeylerinde artış ile serum hormon konsantrasyonlarında (FSH, LH ve testesteron) azalmalar görülmüştür. ${ }^{[26]}$ Yapılan başka bir çalışmada ise yetişkin farelerde, 30 gün boyunca oral olarak $25 \mu \mathrm{g} / \mathrm{kg} /$ gün dozundaki BPA maruziyeti bile düşük epididimal spermatozoa konsantrasyonları ile ilişkili bulunmuştur. ${ }^{[27]}$

\section{INSAN ÇALIȘMALARI}

Bisfenol A'nın erkek üreme sağlığı üzerine olumsuz etkileri in vitro olarak gösterilmiştir. Desdoits-Lethimonier ve ark. tarafından yürütülen bir çalışmada antiandrojen tedavisi veya multiorgan donörü olmayan prostat kanseri hastalarından alınan erişkin insan testis eksplantları $(n=3$, ort. yaş: 46) kültür ortamında BPA'ya ve bisfenol F (BPF), bisfenol S (BPS), bisfenol E (BPE), bisfenol B (BPB) ve bisfenol A diglisidil eter (BADGE) analoglarına $10^{-9}$ ve $10^{-5}$ M dozunda 24 veya 48 saat süre ile maruz bırakılmıştır. Kültür ortamında ölçülen testesteron seviyelerinde BPA,
BPE ve BPF dozuna bağlı olarak 24 ve 48 saatte inhibisyon gözlenmiştir. Testosteron üretiminin BPA ve BPA-A kaynaklı inhibisyonu, maruz kalma süresine ve BPA/BPA-A konsantrasyonlarına göre değişmiştir. Ancak çalışmada düşük sayıda testis örneklerinin yer alması ve araştırmada kullanılan BPA ve BPA-A'nın aktif konsantrasyonlarının insan biyolojik sıvılarında bulunanlardan daha yüksek düzeyde olması çalışmayı kısıtlayıcı faktörler olarak bildirilmiştir. ${ }^{[28]}$

Birçok epidemiyolojik çalışma ise BPA'nın erkek üreme sağlığı ile olan ilişkisini araştırmıştır (Tablo 2). Öncelikle, gebelik döneminde mesleki BPA maruziyeti olan ebeveynlerden doğan 56 erkek çocuk ile BPA maruziyeti olmayan ebeveynlerden doğan 97 erkek çocukta yapılan bir kohort çalışmada; gebelik döneminde BPA'ya ebeveynlerin mesleki maruziyeti; erkek çocuklarda kısalmış anogenital aralık ile ilişkilendirilmiştir. ${ }^{[29]}$ Ferguson ve arkadaşlarının 8-14 yaş 118 erkek ile yürüttükleri bir retrospektif kohort çalışmada ise BPA'ya prenatal maruziyet; adrenarş oranında $(\mathrm{OR}=0,12$ ile 0,65$)$ ve puberte oranlarında azalmayla $(\mathrm{OR}=0,50$ ile 0,98) ilişkili bulunurken; BPA'ya çocukluk çağı maruziyeti adrenarş ya da puberte ile ilişkili bulunmamıştır. ${ }^{\left[{ }^{[0]}\right]}$ İnsanlar üzerinde yapilan bu çalışmalar BPA'ya özellikle prenatal maruziyetin erkek üreme sağlı̆̆ını olumsuz yönde etkilediğini vurgulamaktadır.

Yaşamın yetişkinlik dönemini kapsayan epidemiyolojik çalışmalar ise BPA'nın sperm parametreleri, infertilite ve üreme hormonları ile olan ilişkilerini incelemiştir. Li ve arkadaşlarının bir işyerinde BPA maruziyeti olan ve olmayan 218 Çinli erkek üzerinde yürüttükleri bir çalışmada idrar BPA düzeyindeki (1,4-38,7 $\mu \mathrm{g} / \mathrm{L})$ artış; sperm konsantrasyonun, toplam sperm sayısının, sperm vitalitesinin ve motilitesinin azalması ile ilişkilendirilmiştir. [31] Adoamnei ve ark.'nın 215 Güney İspanya'lı üniversite öğrencisi ile yürüttükleri bir çalışmada idrar BPA seviyeleri sperm konsantrasyonu ve toplam sperm sayıs ile ters ilişkilendirilmiştir. ${ }^{[19]}$ Danimarkalı 308 genç erkek üzerinde yürütülen bir çalışmada ise idrar BPA seviyeleri hareketli sperm yüzdesi ile negatif ilişkili bulunmuştur. ${ }^{\text {[2] }}$ İdrar BPA seviyelerinin sperm parametreleri üzerine olumsuz etkisini desteklemeyen çalışmalar da mevcuttur. Gebelik için doğum kontrolünü bırakan çiftlerin erkek partnerleri $(n=418)$ ile yürütülen bir çalışmada, idrar BPA ve semen parametreleri arasında bir ilişki saptanmamıştır. ${ }^{[33]}$ Gebe kadınların ( $n=375)$ eşleri üzerinde yapılan bir başka çalışmada da idrar BPA seviyeleri ve semen parametreleri arasında bir ilişki bulunmamıştır. ${ }^{[34]}$ İnfertilite kliniğine başvuran 191 Çek erkek ile yürütülen bir kohort çalışmada ise erkekler WHO 2010 kriteri spermiyogramlarına göre 4 gruba ayrılmışlardır ve 1 . grup normal spermiyograma 
Tablo 2. Insanlar üzerinde yapılan çeşitli çalışmalar

\begin{tabular}{|c|c|c|c|c|c|}
\hline Referans & Çalışma Tipi & BPA düzeyi & Katılımcılar & $\begin{array}{l}\text { BPA Ölçüm } \\
\text { Metodu }\end{array}$ & Sonuç \\
\hline $\begin{array}{l}\text { Meeker ve ark. } \\
2010^{[51]}\end{array}$ & $\begin{array}{l}\text { Prospektif } \\
\text { kohort }\end{array}$ & $1,3 \mathrm{ng} / \mathrm{mL}$ & $\begin{array}{l}\text { İnfertilite kliniğine } \\
\text { başvuran } 190 \text { erkek }\end{array}$ & $\begin{array}{l}\text { İdrar } \\
\text { Semen }\end{array}$ & $\begin{array}{l}\text { İdrar BPA seviyeleri azalmış semen } \\
\text { kalitesi ve artmış sperm hasarı ile } \\
\text { ilişkili bulunmuştur. }\end{array}$ \\
\hline Liu ve ark. 2015..$^{[20]}$ & Kesitsel & $0.5-45.6 \mu \mathrm{g} / \mathrm{gCr}$ & $\begin{array}{l}165 \text { BPA maruziyeti olan } \\
\text { fabrika işçileri } \\
427 \text { BPA maruziyeti } \\
\text { olmayan iş̧̧iler }\end{array}$ & $\begin{array}{l}\text { İdrar } \\
\text { Kan }\end{array}$ & $\begin{array}{l}\text { Yükselmiş idrar BPA düzeyi artmış } \\
\text { prolaktin, östradiol, cinsiyet hormonu } \\
\text { bağlayıcı globulin düzeyi ve azalmış } \\
\text { serbest androjen indeks düzeyi ile } \\
\text { ilişkilidir. }\end{array}$ \\
\hline $\begin{array}{l}\text { Den Hond ve ark. } \\
\text { 2015. }{ }^{[37]}\end{array}$ & Vaka-kontrol & $1,5-1,6 \mathrm{ng} / \mathrm{mL}$ & $\begin{array}{l}\text { Bir fertilite kliniğine } \\
\text { başvuran erkekler } \\
\text { Kontrol: } 80 \\
\text { Vaka:40 }\end{array}$ & $\begin{array}{l}\text { İdrar } \\
\text { Kan } \\
\text { Semen }\end{array}$ & $\begin{array}{l}\text { BPA ve serum testesteron negatif } \\
\text { ilişkilidir. }\end{array}$ \\
\hline Vitku ve ark. $2015^{[52]}$ & vaka-kontrol & $\begin{array}{l}\text { Seminal BPA } \\
\text { (pg/m): } \\
\text { Grup 1: } 47 \\
\text { Grup 2: } 137 \\
\text { Grup 3: } 114 \\
\text { Grup 4: } 33 \\
\text { Plazma BPA } \\
\text { (pg/m): } \\
\text { Grup 1: } 66 \\
\text { Grup 2: } 144 \\
\text { Grup 3: } 132 \\
\text { Grup 4: } 179\end{array}$ & $\begin{array}{l}\text { WHO spermiyogram } \\
\text { kriterlerine göre } 4 \text { gruba } \\
\text { ayrılan farklı } 174 \text { erkek } \\
\text { Grup } 1 \\
\text { (sağlıklı erkekler): } 84 \\
\text { Grup } 2 \text { (hafif infertil): } 56 \\
\text { Grup } 3 \text { orta düzeyde } \\
\text { infertil): } 20 \\
\text { Grup } 4 \text { (şiddetli düzeyde } \\
\text { infertil): } 14\end{array}$ & $\begin{array}{l}\text { Plazma, } \\
\text { Seminal } \\
\text { plazma }\end{array}$ & $\begin{array}{l}\text { Sadece seminal sıvıdaki BPA düzeyi } \\
\text { sperm konsantrasyonu ve total sperm } \\
\text { sayısı ile negatif ilişkilidir. } \\
\text { Her iki vücut sıvısında BPA ve E2 pozitif } \\
\text { ilişkidir. }\end{array}$ \\
\hline
\end{tabular}

sahip normospermik erkekler (89 kişi), 2. grup oligospermik, astenospermik, oligoastenospermik erkekler (59 kişi), 3. grup teratospermik, oligoastenoteratospermik (25 kişi), 4. grup azoospermik (18 kişi) erkeklerden oluşmuştur. İdrar BPA'ya ek olarak semendeki BPA'nın ölçülmesi bu çalışmayı diğerlerinden farklı kılmıştır. Çalışmada seminal BPA seviyeleri, infertilite şiddetinin artması ile pozitif ilişkili bulunurken, sperm konsantrasyonu, sayısı ve morfolojisi ile negatif ilişkilendirilmiştir. Ayrıca, LH ve FSH gibi hormonların BPA ile ilişkili bulunmadığı ve hem üriner hem de seminal BPA'nın E2 ile pozitif ilişkili olduğu gözlenmiştir. E2 seviyesindeki yüksekliğin periferde veya testiste aromataz enziminin yeniden aktivasyonundaki artıştan kaynaklanabileceği belirtilmiştir. ${ }^{[35]}$ Çin'de 877 idiyopatik infertil erkek ve 713 fertil kontrolün araştırma kapsamına alındığı bir vaka-kontrol çalışmasında ise BPA ve idiyopatik erkek infertilitesi arasında ilişki bulunmamıştır. ${ }^{\left[{ }^{[6]}\right]}$ BPA'nın üreme hormonlarına olan etkisini inceleyen çalışmaların bazılarında idrarda BPA seviyeleri serum LH seviyeleri ile pozitif olarak ilişkilendirilmiştir. ${ }^{[19,32]} \mathrm{BPA}$ ve serum testesteron seviyeleri arasındaki ilişkiyi inceleyen çalışmalarda ise tutarsızlık vardır. Bir çalışmada idrar BPA düzeyleri ile testesteron seviyeleri arasında negatif ilişki bulunurken, ${ }^{[37]}$ diğer bir çalışmada pozitif ilişki bulunmuştur. ${ }^{[38]}$ Ayrıca bir çalışmada idrar BPA seviyeleri ile serum cinsiyet hormon bağlayıcı globülin (SHBG) seviyelerinin pozitif ilişkili olduğu ve idrar BPA konsantrasyonu ve serbest androjen indeksi (FAI) seviyeleri ile FAI/LH oranı arasında anlamlı bir ters ilişki bulunduğu rapor edilmiştir. ${ }^{[34]}$ Ayrıca, Zhuang ve ark.'nın Çin'de BPA maruziyeti olan 281 fabrika işçisi ve 278 kontrolü ile yürüttükleri bir çalışmada iki grup arasında serum BPA düzeyleri (sırası ile; 18,75 ve $3,37 \mathrm{ng} / \mathrm{mL}$ ) anlamlı düzeyde farklı bulunurken; SHBG, total testesteron, androstenedion (testesteron sentezinin öncüsü) ve inhibin B hormonlarında anlamlı bir fark gözlenmemiştir. Ancak, çalışma yılı $\geq 5$ yıl olan işçilerde, çalışma yılı $\leq 5$ yıl olan işçilere kıyasla anlamlı düzeyde artmış serum BPA ve SHBG ile azalmış düzeyde androstenedion seviyeleri bildirilmiştir. ${ }^{[39]}$ Diğer bir çalışmada ise, idrar BPA seviyeleri serum FSH ve FSH: İnhibin B seviyeleri ile pozitif ilişkili bulunmuştur. ${ }^{[40]}$

\section{POTANSIYEL MEKANIZMALAR}

Yapılan bazı hayvan çalışmaları BPA'nın erkek üreme sağlığındaki olumsuz etkileri açıklayabilecek potansiyel mekanizmalara ışık tutmuştur. Bu mekanizmalar özellikle nükleer morfolojideki değişiklikler ile açıklanmaktadır. Nükleer morfolojideki değişiklikler genel olarak bir hücrenin içinde yer alan ve proliferasyon, gen ekspresyonu ve protein sentezi ile sıkı bir şekilde ilişkili olduğu bilinen milyonlarca hücresel olayın bir yansıması ya da bir sonucudur. Bu nedenle, 
nükleer morfoloji, toksikolojik analizler için yararlı bir "okuma" dır. Çekirdek, kromozomları sitoplazmadan izole eden ve tipik olarak oval veya yuvarlak bir şekle sahip olan nükleer zarla çevrelenmiştir. ${ }^{[4]}$ Çeşitli araştırmalar BPA'nın nükleer morfolojide değişikliklere neden olarak erkek üreme sağlığı$\mathrm{n} ı$ olumsuz etkilediğine dair veriler sunmaktadır. Liang ve ark.'nın üç ticari BPA analoğunun (BPS, BPAF ve TBBPA) testis toksisitelerini karakterize etmek ve karşılaştırmak için yürüttükleri bir araştırmada BPAF ve TBBPA'nın, BPA ve BPS'ye kıyasla daha yüksek spermatogonial toksisite gösterdiği, nükleer morfolojide doz ve zamana bağlı değişiklikler, hücre döngüsü, DNA hasar yanıtları ve hücre iskeleti pertürbasyonunu gösterdiği rapor edilmiştir. ${ }^{[4]}$ Yenidoğan erkek farelerde yapılan bir başka çalışmada ise doğum sonrası 1 ile 21. günler arasında $(0,01,0,1$ ve $5 \mathrm{mg} / \mathrm{kg}$ vücut ağırlı$\left.\breve{g}_{1}\right)$ deri altından BPA enjekte edilen farelerin testislerinde, spermatogenez için gerekli olduğu bilinen DAZ (Deleted in AZoospermia) ailesinin bir üyesi olan BOULE ekspresyonunun tam bir eksikliğinin gözlendiği ve BPA'nın gelişmekte olan testiste östrojen reseptörü $\alpha$ ve $\beta$ ekspresyonunu anlamlı şekilde arttırdığı rapor edilmiştir. Bu çalışma ile neonatal BPA maruziyetinin, en azından kısmen BOULE ekspresyonunun inhibe edilmesinden ve/veya BPA-maruz gelişen testiste $\mathrm{Er} \alpha / \beta$ ekspresyonunun up-regülasyonuna bağlı olarak, ilk spermatogenez dalgası sırasında mayoz gelişimini bozduğunu göstermiştir. ${ }^{[42]}$ Ayrıca, mitokondriyal proteinlerin fosforilasyonunun, sperm hareketliliğini artt1ran ATP'yi üretmek için mitokondriyal biyojenezi düzenlediği ve sperm hareketliliğinin, esas olarak tirosin kalıntıları üzerinde, cAMP-bağımlı ve sperm proteinlerinin protein kinaz A (PKA) aracılı fosforilasyonu ile düzenlendiği bilinmektedir. Bu konuda; gebe farelerin (F0), 7 ile 14 arasındaki embriyonik günlerde üç farklı dozda $(50 \mu \mathrm{g} / \mathrm{kg} / \mathrm{gün}, 5 \mathrm{mg} /$ $\mathrm{kg} /$ gün ve $50 \mathrm{mg} / \mathrm{kg} /$ gün) BPA ile beslendikleri bir çalışmada; BPA'nın doza bağımlı olarak sperm sayısını, hareketlilik parametrelerini ve hücre içi ATP seviyelerini inhibe ettiği ve bu etkilerin spermatozoada PKA aktivitesinin ve tirozin fosforilasyonunun azalmasından kaynaklandığı belirtilmiştir. ${ }^{[8]}$ BPA'nın olgun spermler üzerindeki etki mekanizmalarını araştıran bir çalışmada ise $200 \mathrm{mg} / \mathrm{kg} /$ gün BPA ile beslenen erkek sıçanların epididimal sperm motilitesinde anlamlı bir artış olduğu gözlenmiştir. Ayrıca, BPA'nın in vitro maruziyetinin, PKA'yı aktive ederek sıçan sperminin kapasitansı ile ilişkili protein tirozin fosforilasyonunu hızlandırabildiği bulunmuştur ve BPA stimülasyonu ile artan kapasitansın, sperm ve embriyo gelişimi için zararlı olacağı bildirilmiştir. Ayrıca, bu çalışmada 200 mg/kg'lık yüksek dozda BPA'ya maruz bırakılan sıçanların sperm motilitesinde önemli bir artış gözlenmesinin; BPA'ya 0,2, 2 ve $20 \mu \mathrm{g} / \mathrm{kg}$ dozlarında maruziyetin epididimal sperm motilitesinde azalmaya neden olduğu sonucuna ters olduğu ve BPA'nın üreme fonksiyonu üzerindeki etkisinin, düşük ve yüksek dozaj koşullarındaki farklılığını yansıttığı bildirilmiştir. Öte yandan bu veriler; BPA uygulaması, BPA dozu ve BPA maruz kalma süresi arasındaki farkın farklı yanıtlar ile sonuçlanabileceğini göstermektedir. ${ }^{[43]}$

Yukarıda sözü edilen mekanizmalara ek olarak, ayrıca sperm plazma membranında bulunan iki çeşit sperm spesifik iyon kanalı, Ca2+ geçirgen CatSper (spermin katyon kanalı) ve K-geçirgen KSper'in (sperm pH'sı düzenlenmiş $\mathrm{K}+$ kanalı) sperm fertilizasyonu için çok önemli olduğu belirlenmiştir. Olgun fare spermatozoası üzerine BPA'nın in vivo ve in vitro toksisitesini araştırmayı amaçlayan bir araştırmada; farklı dozlarda BPA $(0,10,50$ ve $250 \mu \mathrm{g}$ $\mathrm{kg}-1$. d-1) 8 hafta boyunca farelere oral yoldan uygulandığında; farelerde sperm motilitesinde ve akrozom reaksiyonunda (AR) gözlenen anlamlı düşüşlerin BPA'nın neden olduğu CatSper down-regülasyonundan kaynaklandığı düşünülmüştür. Ayrıca, BPA'nın spermatozoaya doğrudan uygulanmasının, CatSper'ı geçici olarak inhibe ettiği ve aynı zamanda sperm toplam motilitesi ve AR oranında önemli düzeyde azalmaya neden olduğu rapor edilmiştir. Bu çalışmada, BPA'nın in vivo ve in vitro uygulanmasının, CatSper ile ilgili bir mekanizma ile olgun sperm fonksiyonlarını bozduğu sonucuna varılmıştır. ${ }^{[4]}$

Son olarak, BPA gibi çevresel kontaminantların fertilite üzerinde uzun süreli etkilerinin epigenetik mekanizmalar aracılı̆̆ı ile olabileceği düşünülmektedir. Epigenetik, DNA sekansında değişiklikler içermeyen, gen ekspresyonunda kalıtsal ve kararlı değişimlerden sorumlu moleküler süreçlerle ilgili geniş bir çalışma alanıdır. DNA dizisi sabit kalmasına rağmen, genlerin ve gen bölgelerinin ifadesi veya susturulması, çeşitli çevresel maruziyetlere yanıt olarak DNA metilasyonu gibi çeşitli epigenetik mekanizmalar aracılı̆̆ıyla elde edilebilir. BPA'ya perinatal maruziyetin testiküler steroid hormon reseptörlerinin sayısında, sperm motilitesinde ve sperm sayısında transgenerasyonel değişiklikler oluşturabileceği düşünülmektedir. ${ }^{[45]}$ Yapılan bir çalışmada BPA'nın fare hücrelerinin proliferasyonunu inhibe etmesi, DNA replikasyon kapasitesini azaltması, spermatositlerde apoptozu tetiklemesi DNA metilasyonunun BPA maruziyetine bağlı olarak erkek üreme toksisitesinde rol oynayabileceğini göstermiştir. ${ }^{[46]}$ Mesleki olarak BPA'ya maruz kalan 30 erkeğin ve 26 kontrolün sperm örnekleri ile yapılan bir çalı̧̧mada ise 5-hidroksimetilsitosinin (5 hmc) toplam seviyeleri, mesleki BPA maruziyeti olmayan kontrollerle karşılaştırıldığında, BPA'ya maruz kalan erkeklerin spermlerinde önemli ölçüde artmıştır. Bu bulgulara göre gen ekspresyonundaki değişimlere bağlı olarak BPA'nın spermlerde daha düşük yoğunluğa ve motiliteye sebep olabileceği rapor edilmiştir. ${ }^{[4]]}$ 


\section{SONUÇ}

BPA ve erkek üreme sağlığı üzerine yapılan çalışmalar; BPA'nın üreme sistemi üzerindeki etkilerinin değişken olduğunu ve gözlenen etkilerin önerilen güvenli günlük alım düzeyleri olan $4-50 \mu \mathrm{g} / \mathrm{kg} / \mathrm{gün}$ dozlarında belirgin olarak ortaya çıktığını göstermektedir. Ayrıca, NOAEL ve LOAEL dozları spermatogenez üzerinde ve çeşitli sperm parametrelerinde ciddi düzeyde toksik etkilere sahip olmasından ve maruz kalan bireylerde doğurganlığı etkileyebilecek değişiklikler açığa çıkarmasından dolayı günümüzde kabul edilen BPA maruziyet düzeylerini yeniden değerlendirmek halk sağlığı açısından büyük bir önem taşımaktadır. BPA erkek üreme sağlığını; sperm kalitesine, infertiliteye, hormonlara ve cinsel işlev üzerine olan etkileri aracılığı ile negatif yönde etkileyebilmektedir. Hayvan çalışmalarında BPA'nın sperm üretimini, kalitesini ve hormon sentezini değiştirdiği ve özellikle testesteron hormonunun düzeyinde anlamlı değişikliklere neden olduğu gözlenmiştir. Ayrıca, hayvan çalışmaları BPA'ya özellikle utero döneminde maruziyetin genellikle yavrularda üreme sağlığını olumsuz ve kalıcı olarak etkilediğini bildirmiştir. Nükleer morfolojideki değişikliklerin ve DNA metilasyonu gibi gen ekspresyonunu etkileyen epigenetik mekanizmaların BPA gibi çevresel kontaminantlara yanıt olarak üreme sağlığı üzerinde olumsuz etkilere neden olabilecek potansiyel mekanizmalar olabileceği düşünülmektedir. Epidemiyolojik çalışmalar da BPA’nın insanlarda erkek üreme sağlığını değiştirdiğini gösteren bulgular sağlamıştır. Ancak, çalışmalarda idrar BPA konsantrasyonu ve erkek üreme sağlı̆̆ tekleyen kanıtlar sınırlıdır. Yapılan çalışmalarda BPA'ya maruz kalan erkeklerin idrarlarındaki yüksek BPA seviyesi; anormal semen parametreleri ile ilişkilendirilmiştir. İnsan çalışmalarında da BPA'nın hormonlar üzerine etki göstermesi BPA'nın erkeklerde steroid hormon yollarını değiştirebileceğini düşündürmektedir. Ancak, BPA ve hormonları ilişkilendiren çalışmaların az sayıda olması ve tutarsız sonuçlar vermesi; BPA'nın steroidojenezi nasıl etkilediğini belirlemek için daha fazla çalışmaya ihtiyaç olduğunu göstermektedir. İnsan çalısmalarındaki tutarsızlıkların sebepleri incelendiğinde; bu durumun çalışmalarda yer alan popülasyonların farklı olmasından kaynaklı olabileceği ve subfertil erkeklerin fertil erkeklere kıyasla BPA'nın etkilerine daha hassas olabilecekleri düşünülmektedir. Ayrıca, çalışmalarda vücuttaki BPA düzeyini ölçmek için genellikle sadece idrar örnekleri kullanılmıştır ve çalışmalarda idrar BPA seviyelerinin farklılık göstermesi de bir tutarsızlık nedeni olarak düşünülmektedir. Ayrıca, semen parametreleri ve üreme hormonları ile ilgili çalışmaların çoğunluğu nedensel sonuç vermeyen kesitsel çalışmalardır. Bu yüzden mekanizmalar çok net değildir. Sonuç olarak; insan çalışmaları genellikle BPA'nın yetişkin dönemindeki erkek maruziyetini ölçmüştür ve BPA'nın etkilerine daha duyarlı olabilecek erken yaşam dönemlerini kapsayan (örn., prenatal veya peripubertal dönemler gibi) çalışmalar yetersiz sayıdadır.

\section{Hakem Değerlendirmesi}

Dış bağımsız

Çıkar Çatışması

Yazarlar çıkar ilişkisi olmadığını beyan etmişlerdir.

Finansal Destek

Herhangi bir mali destek alınmamıştır.

Peer-review

Externally peer-reviewed.

Conflict of Interest

No conflict of interest was declared by the authors.

Financial Disclosure

No financial disclosure was received.

\section{KAYNAKLAR}

1. Ayazgök B, Tüylü Küçükkılınç T. Düşük Doz Bisfenol A’nın Büyük Etkileri. FABAD J Pharm Sci 2017;42:139-50.

2. What are endocrine disruptors? Agency., U. S. E. P. Retrieved from: https://www.epa.gov/endocrine-disruption/what-endocrinedisruption

3. Huang YQ, Wong CK, Zheng JS, Bouwman H, Barra R, Wahlström B, et al. Bisphenol A (BPA) in China: A review of sources, environmental levels, and potential human health impacts. Environ Int 2012;42:91-9. [CrossRef]

4. Jalal N, Surendranath AR, Pathak JL, Yu S, Chung CY. Bisphenol A (BPA) the mighty and the mutagenic. Toxicol Rep 2018;5:7684. [CrossRef]

5. Michałowicz J. Bisphenol A - Sources, toxicity and biotransformation. Environ Toxicol Pharmacol 2014;37:738-58. [CrossRef]

6. Rochester JR. Bisphenol A and human health: A review of the literature. Reprod Toxicol 2013;42:132-55. [CrossRef]

7. Manfo FP, Jubendradass R, Nantia EA, Moundipa PF, Mathur PP. Adverse Effects of Bisphenol A on Male Reproductive Function. Rev Environ Contam Toxicol 2014;228:57-82. [CrossRef]

8. Rahman MS, Kwon WS, Karmakar PC, Yoon SJ, Ryu BY, Pang MG. Gestational Exposure to Bisphenol A Affects the Function and Proteome Profile of F1 Spermatozoa in Adult Mice. Environ Health Perspect 2017;125:238-45. [CrossRef]

9. Bolt HM, Stewart JD. Highlight report: the bisphenol A controversy. Arch Toxicol 2011;85:1491-2. [CrossRef]

10. Rubin BS. Bisphenol A. an endocrine disruptor with widespread exposure and multiple effects. J Steroid Biochem Mol Biol 2011;127:27-34. [CrossRef]

11. EFSA 2015. https://www.efsa.europa.eu/en/topics/topic/bisphenol Accessed: 30.04.2018.

12. Sözlü S, Akdevelioğlu Y. Bisfenol A (BFA) ve insan üreme sağlığ1. Mersin Üniversitesi Sağlık Bilimleri Dergisi 2018;11:86-9. [CrossRef]

13. Vandenberg LN, Hauser R, Marcus M, Olea N, Welshons WV. Human exposure to bisphenol A (BPA). Reprod Toxicol 2007;24:139-77. [CrossRef] 
14. Nanjappa MK, Simon L, Akingbemi BT. The industrial chemical bisphenol A (BPA) interferes with proliferative activity and development of steroidogenic capacity in rat Leydig cells. Biol Reprod 2012;86:135, 1-12. [CrossRef]

15. Smith LB, Walker WH. The regulation of spermatogenesis by androgens. Semin Cell Dev Biol 2014;30:2-13. [CrossRef]

16. Stuppia L, Franzago M, Ballerini P, Gatta V, Antonucci I. Epigenetics and male reproduction: the consequences of paternal lifestyle on fertility, embryo development, and children lifetime health. Clin Epigenetics 2015;7:120. [CrossRef]

17. Creasy DM, Chapin RE. Male Reproductive System. In: Haschek W, Rousseaux C, Wallig M, editors. Haschek and Rousseaux's Handbook of Toxicologic Pathology, 3rd ed. USA: Elsevier; 2013. pp.2493-598.

18. Oliva A, Spira A, Multigner L. Contribution of environmental factors to the risk of male infertility. Hum Reprod 2001;16:176876. [CrossRef]

19. Adoamnei E, Mendiola J, Vela-Soria F, Fernández MF, Olea $\mathrm{N}$, Jørgensen $\mathrm{N}$, et al. Urinary bisphenol A concentrations are associated with reproductive parameters in young men. Environ Res 2018;161:122-8. [CrossRef]

20. Liu X, Miao M, Zhou Z, Gao E, Chen J, Wang J, et al. Exposure to bisphenol-A and reproductive hormones among male adults. Environ Toxicol Pharmacol 2015;39:934-41. [CrossRef]

21. vom Saal FS, Cooke PS, Buchanan DL, Palanza P, Thayer KA, Nagel SC, et al. A physiologically based approach to the study of bisphenol $\mathrm{A}$ and other estrogenic chemicals on the size of reproductive organs, daily sperm production, and behavior. Toxicol Ind Health 1998;14:239-60. [CrossRef]

22. Kawai K, Nozaki T, Nishikata H, Aou S, Takii M, Kubo C. Aggressive behavior and serum testosterone concentration during the maturation process of male mice: the effects of fetal exposure to bisphenol A. Environ Health Perspect 2003;111:175-8. [CrossRef]

23. Xi W, Wan HT, Zhao YG, Wong MH, Giesy JP, Wong CK. Effects of perinatal exposure to bisphenol A and di(2-ethylhexyl)-phthalate on gonadal development of male mice. Environ Sci Pollut Res Int 2011;19:2515-27. [CrossRef]

24. Howdeshell KL, Furr J, Lambright CR, Wilson VS, Ryan BC, Gray LE Jr. Gestational and Lactational Exposure to Ethinyl Estradiol, but not Bisphenol A, Decreases Androgen-Dependent Reproductive Organ Weights and Epididymal Sperm Abundance in the Male Long Evans Hooded Rat. Toxicol Sci 2008;102:37182. [CrossRef]

25. Herath CB, Jin W, Watanabe G, Arai K, Suzuki AK, Taya K. Adverse effects of environmental toxicants, octylphenol and bisphenol A, on male reproductive functions in pubertal rats. Endocrine 2004;25:163-72. [CrossRef]

26. Wisniewski P, Romano RM, Kizys MM, Oliveira KC, Kasamatsu T, Giannocco G, et al. Adult exposure to bisphenol A (BPA) in Wistar rats reduces sperm quality with disruption of the hypothalamicpituitary-testicular axis. Toxicology 2015;329:1-9. [CrossRef]

27. Al-Hiyasat AS, Darmani H, Elbetieha AM. Effects of bisphenol A on adult male mouse fertility. Eur J Oral Sci 2002;110:163-7. [CrossRef]

28. Desdoits-Lethimonier C, Lesné L, Gaudriault P, Zalko D, Antignac JP, Deceuninck Y, et al. Parallel assessment of the effects of bisphenol A and several of its analogs on the adult human testis. Hum Reprod 2017;32:1465-73. [CrossRef]

29. Miao M, Yuan W, He Y, Zhou Z, Wang J, Gao E, et al. In utero exposure to bisphenol-A and anogenital distance of male offspring. Birth Defects Res A Clin Mol Teratol 2011;91:867-72. [CrossRef]
30. Ferguson KK, Peterson KE, Lee JM, Mercado-García A, BlankGoldenberg C, Téllez-Rojo MM, Meeker JD. Prenatal and peripubertal phthalates and bisphenol A in relation to sex hormones and puberty in boys. Reprod Toxicol 2014;47:70-6. [CrossRef]

31. Li DK, Zhou Z, Miao M, He Y, Wang J, Ferber J, et al. Urine bisphenol-A (BPA) level in relation to semen quality. Fertil Steril 2011;95:625-30.e4. [CrossRef]

32. Lassen TH, Frederiksen H, Jensen TK, Petersen JH, Joensen UN, Main KM, et al. Urinary bisphenol A levels in young men: association with reproductive hormones and semen quality. Environ Health Perspect 2014;122:478-84. [CrossRef]

33. Goldstone AE, Chen Z, Perry MJ, Kannan K, Louis GMB. Urinary bisphenol A and semen quality, the LIFE Study. Reprod Toxicol 2015;51:7-13. [CrossRef]

34. Mendiola J, Jørgensen N, Andersson AM, Calafat AM, Ye X, Redmon JB, et al. Are environmental levels of bisphenol a associated with reproductive function in fertile men? Environ Health Perspect 2010;118:1286-91. [CrossRef]

35. Vitku J, Heracek J, Sosvorova L, Hampl R, Chlupacova T, Hill M, et al. Associations of bisphenol A and polychlorinated biphenyls with spermatogenesis and steroidogenesis in two biological fluids from men attending an infertility clinic. Environ Int 2016;8990:166-73. [CrossRef]

36. Chen M, Tang R, Fu G, Xu B, Zhu P, Qiao S, et al. Association of exposure to phenols and idiopathic male infertility. J Hazard Mater 2013;250-251:115-21. [CrossRef]

37. Den Hond E, Tournaye H, De Sutter P, Ombelet W, Baeyens W, Covaci A, et al. Human exposure to endocrine disrupting chemicals and fertility: A case-control study in male subfertility patients. Environ Int 2015;84:154-60. [CrossRef]

38. Takeuchi T, Tsutsumi O. Serum bisphenol a concentrations showed gender differences, possibly linked to androgen levels. Biochem Biophys Res Commun 2002;291:76-8. [CrossRef]

39. Zhuang W, Wu K, Wang Y, Zhu H, Deng Z, Peng L, Zhu G. Association of serum bisphenol-A concentration and male reproductive function among exposed workers. Arch Environ Contam Toxicol 2015;68:38-45. [CrossRef]

40. Meeker JD, Calafat AM, Hauser R. Urinary bisphenol A concentrations in relation to serum thyroid and reproductive hormone levels in men from an infertility clinic. Environ Sci Technol 2010;44:1458-63. [CrossRef]

41. Liang S, Yin L, Shengyang Yu K, Hofmann MC, Yu X. HighContent Analysis Provides Mechanistic Insights into the Testicular Toxicity of Bisphenol A and Selected Analogues in Mouse Spermatogonial Cells. Toxicol Sci 2017;155:43-60. [CrossRef]

42. Xie M, Bu P, Li F, Lan S, Wu H, Yuan L, Wang Y. Neonatal bisphenol A exposure induces meiotic arrest and apoptosis of spermatogenic cells. Oncotarget 2016;7:10606-15. [CrossRef]

43. Wan X, Ru Y, Chu C, Ni Z, Zhou Y, Wang S, et al. Bisphenol A accelerates capacitation-associated protein tyrosine phosphorylation of rat sperm by activating protein kinase A. Acta Biochim Biophys Sin (Shanghai) 2016;48:573-80. [CrossRef]

44. Wang HF, Liu M, Li N, Luo T, Zheng LP, Zeng XH. Bisphenol A Impairs Mature Sperm Functions by a CatSper-Relevant Mechanism. Toxicol Sci 2016;152:145-54. [CrossRef]

45. Doshi T, Mehta SS, Dighe V, Balasinor N, Vanage G. Hypermethylation of estrogen receptor promoter region in adult testis of rats exposed neonatally to bisphenol A. Toxicology 2011;289:74-82. [CrossRef]

46. Yin L, Dai Y, Jiang X, Liu Y, Chen H, Han F, et al. Role of DNA methylation in bisphenol A exposed mouse spermatocyte. Environ Toxicol Pharmacol 2016;48:265-71. [CrossRef] 
47. Zheng H, Zhou X, Li DK, Yang F, Pan H, Li T, et al. Genomewide alteration in DNA hydroxymethylation in the sperm from bisphenol A-exposed men. PLoS One 2017;12:e0178535. [CrossRef]

48. Liu C, Duan W, Li R, Xu S, Zhang L, Chen C, et al. Exposure to bisphenol A disrupts meiotic progression during spermatogenesis in adult rats through estrogen-like activity. Cell Death Dis 2013;4:e676. [CrossRef]

49. Karnam SS, Ghosh RC, Mondal S, Mondal M. Evaluation of subacute bisphenol - A toxicity on male reproductive system. Vet World 2015;8:738-44. [CrossRef]
50. Salian S, Doshi T, Vanage G. Perinatal exposure of rats to Bisphenol A affects the fertility of male offspring. Life Sci 2009;85:742-52. [CrossRef]

51. Meeker JD, Ehrlich S, Toth TL, Wright DL, Calafat AM, Trisini AT, et al. Semen quality and sperm DNA damage in relation to urinary bisphenol A among men from an infertility clinic. Reprod Toxicol 2010;30:532-9. [CrossRef]

52. Vitku J, Sosvorova L, Chlupacova T, Hampl R, Hill M, Sobotka V, et al. Differences in bisphenol A and estrogen levels in the plasma and seminal plasma of men with different degrees of infertility. Physiol Res 2015;64 Suppl 2:S303-11. 